\title{
Pengaruh Motivasi Kerja Terhadap Kinerja Karyawan di Puskesmas Bukit Kayu Kapur, Kota Dumai
}

\author{
Marlianti Hasibuan*, Latip ${ }^{*}$ \\ *Program Ilmu Administrasi Negara, Sekolah Tinggi Ilmu Administrasi Lancang Kuning Dumai \\ Email: hasibuanyanti21@gmail.com
}

\begin{abstract}
Today an organization is demanded to provide quality services and competence, so that it can survive in global competition. The strategy to always be competent is to strengthen the organization's capacity and human resources in order to achieve organizational goals and produce performance that satisfies the community. For that reason, the main thing that must be considered by a leader or manager is how to arouse the passion and motivation of the work of his employees so that employees are able to produce optimal work performance in the organization. The Bukit Kayu Kapur Primary Health Care is a health facility that is useful to achieve the highest degree of public health in the working area, where employees and the Primary Health Care must have good motivation to provide good performance for the Primary Health Care and the community. This study aimed to determine the effect of work motivation on employee performance at the Bukit Kayu Kapur Primary Health Care in Dumai City. This research was a quantitative study. Data obtained by measuring the questionnaire with a Likert scale. Sampling using non-probability methods by means of saturation sampling that is all members of the population used as samples. The number of samples to be used is 64 respondents. Data were analyzed by multiple regression analysis. The analysis showed that partially there was an influence of work motivation on employee performance at the Bukit Kayu
\end{abstract}

Kapur Primary Health Care in Dumai City with a p value <0.05, namely 19.22.

Keywords : Motivation, Performance, Primary Health Care

\section{PENDAHULUAN}

Dewasa ini sebuah organisasi dituntut untuk memberikan pelayanan yang berkualitas dan mampu berkompetensi, sehingga dapat tetap bertahan dalam persaingan global. Strategi untuk selalu dapat berkompetensi adalah dengan cara memperkuat kapasitas organisasi dan sumber daya manusia yang dimiliki guna untuk mencapai tujuan organisasi dan menghasilkan kinerja yang memuaskan masyarakat. Untuk itu, hal utama yang harus diperhatikan seorang pimpinan atau manajer ialah bagaimana membangkitkan gairah dan motivasi kerja karyawannya sehingga karyawan mampu menghasilkan prestasi kerja yang optimal dalam organisasi.

Prestasi kerja seorang karyawan kadangkadang tidak sama dengan kecakapan yang dimilikinya. Tidak sesuainya prestasi kerja dengan kecakapannya bagi seseorang karyawan mungkin karena tidak mempunyai kemauan, bisa juga karena tidak menyukai pimpinannya, pegawai merasa tidak puas dalam bekerja, tidak nyaman dengan lingkungan kerja atau rekan kerja, dan lain sebagainya. ${ }^{1}$ Dalam psikologi keadaan seperti itu dikatakan bukan kecakapan (ability) yang kurang, melainkan motivasi yang kurang atau bahkan tidak ada. 
Seseorang yang memiliki motivasi tinggi akan giat bekerja, sementara yang rendah akan sebaliknya. Seorang karyawan yang termotivasi baik, akan memberikan kontribusi yang lebih besar terhadap organisasinya. Hal ini dapat terlihat dari kinerja yang dicapai oleh setiap karyawan. Sumber daya manusia yang baik akan dimiliki oleh perusahaan yang mengelola sumber dayanya dengan baik agar menghasilkan kinerja yang baik. ${ }^{2}$ Terutama pada perusahaan yang melayani pelayanan kepada masyarakat yang membutuhkan pelayanan yang berkualitas, salah satunya yaitu puskesmas.

Menurut Peraturan Menteri Kesehatan Nomor 75 Tahun 2014, Pusat Kesehatan Masyarakat yang selanjutnya disebut Puskesmas adalah fasilitas pelayanan kesehatan yang menyelenggarakan upaya kesehatan masyarakat dan upaya kesehatan perseorangan tingkat pertama, dengan lebih mengutamakan upaya promotif dan preventif, untuk mencapai derajat kesehatan masyarakat yang setinggi-tingginya di wilayah kerjanya. ${ }^{3}$ Dalam memberikan pelayanan, karyawan harus mampu memberikan pelayanan yang baik yang yang dibuktikan dengan kinerja yang optimal. Namun masih ada indikator kinerja yang belum memenuhi standar dan mendapat komplain dari masyarakat yang berkaitan dengan pelayanan, fasilitas dan administrasi. Penelitian ini bertujuan untuk mengetahui pengaruh motivasi terhadap kinerja karyawan.

\section{METODE PENELITIAN}

Penelitian ini merupakan penelitian kuantitatif. Populasi dalam penelitian ini adalah karyawan (Dokter, bidan, perawat dan staff) Puskesmas Bukit Kayu Kapur Kota Dumai. Pengambilan sampel dilakukan dengan menggunakan metode non-probability dengan cara sampling jenuh yaitu semua angota populasi digunakan sebagai sampel. Jumlah sampel yang akan digunakan yaitu 64 responden.

Penelitian pengukuran kinerja dilakukan dengan menggunakan kuesioner dengan skala likert yang terbagi dengan skor 4 untuk jawaban sangat positif dan 1 untuk jawaban sangat negatif. Kuesioner motivasi terdiri kuesioner keberhasilan, pengakuan, pekerjaan itu sendiri, kemajuan, kebijakan, penghargaan, gaji, hubungan sosial, dan tanggung jawab. Kuesioner Kinerja Karyawan sebanyak 26 butir pernyataan yang terdiri dari beberapa indikator, yaitu: kualitas kerja, tanggung jawab terhadap pekerjaan, kerjasama dengan rekan kerja, motivasi kerja, orientasi kepada pelanggan, inisiatif karyawan.

Uji validitas pada penelitian menggunakan metode korelasi Product Moment Pearson. Suatu butir pernyataan dikatakan valid jika nilai $\mathrm{r}$ hitung $>\mathrm{r}$ tabel,.Dan suatu butir pernyataan dikatakan tidak valid jika nilai $r$ hitung < $\mathrm{r}$ tabel.Uji reliabilitas pada penelitian ini menggunakan metode Cronbach's Alpha. Jika nilai cronbach's alpha > 0,60 maka kuesioner dinyatakan reliabel atau konsisten. Jika nilai cronbach's alpha $<0,60$ maka kuesioner dinyatakan tidak valid atau tidak konsisten. Analisa data yang digunakan dalam penelitian ini adalah analisis regresi berganda yang meliputi analisi korelasi ganda (R), analisis determinasi (R2), dan uji F.

\section{HASIL DAN PEMBAHASAN}

Berdasarkan hasil penelitian menunjukkan responden terbanyak dalam penelitian ini berjenis kelamin perempuan $(64,51 \%)$, pendidikan terakhir S1 $(17,18 \%)$, pendidikan terakhir D3 (70,31\%) pendidikan terakhir SMA $(12,5 \%)$.

\section{Pengaruh Motivasi Terhadap Kinerja Karyawan}

Menurut Ellen A. Benowitz (2001) menyatakan bahwa motivasi merupakan kekuatan yang menyebabkan individu bertindak dengan cara tertentu. ${ }^{4}$ Menurut Silalahi (2002) bahwa motivasi sebagai dorongan dari dalam diri individu berdasarkan mana dari berperilaku dengan cara tertentu untuk memenuhi keinginan dan kebutuhannya. ${ }^{5}$ Sehingga dapat dikatakan bahwa motivasi adalah kegiatan memberikan dorongan kepada seseorang atau diri sendiri untuk mengambil suatu tindakan yang dikehendaki. Jadi motivasi berarti 
membangkitkan motif, daya gerak, atau menggerakkan seseorang atau diri sendiri untuk bertindak dalam rangka mencapai suatu kepuasaan atau suatu tujuan.

Berdasarkan hasil penelitian, dapat diketahui bahwa motivasi berpengaruh positif terhadap kinerja karyawan pada Puskesmas Bukit Kayu Kapur Kota Dumai yang ditunjukkan dengan nilai $\mathrm{p}<0,05$ dan nilai $f_{\text {hitung }}$ lebih besar dari $F_{\text {tabel }}(19,22>3,148)$. Pada analisis koefisien determinasi menunjukkan nilai adjusted $R$ square (R2) yaitu sebesar 0,622 yang artinya bahwa variabel motivasi memberikan kontribusi pengaruh terhadap kinerja karyawan sebesar $38,44 \%$ dan sisanya $37 \%$ ditentukan oleh variabel lain. Penelitian ini sejalan dengan penelitian pada tahun 2015 mengenai kinerja petugas dalam pencatatan dan pelaporan PWS KIA. Penelitian tersebut juga menyatakan bahwa motivasi bidan merupakan salah satu faktor yang berhubungan dengan kinerja bidan. $^{6}$

Hasil analisis menunjukkan bahwa secara parsial ada pengaruh signifikan motivasi terhadap kinerja karyawan pada Puskesmas Bukit Kayu Kapur (fhitung 19,22> ftabel 3,148). Hasil ini menunjukkan hubungan antar motivasi terhadap kinerja karyawan adalah positif yang artinya jika motivasi kerja meningkat, maka kinerja karyawan juga akan meningkat dan berpengaruh secara signifikan terhadap kinerja karyawan. Hasil penelitian ini juga dibuktikan pada penelitian sebelumnya di Kabupaten Morowali yang menyatakan bahwa motivasi kerja secara parsial berpengaruh positif terhadap kinerja pegawai honor lepas pada puskesmas di Kabupaten Morowali. ${ }^{7}$

Motivasi kerja seorang karyawan bersama dengan kedisiplinan, beban kerja, fasilitas kerja, masa kerja, dan lingkungan kerja memiliki pengaruh signifikan terhadap kinerja karyawan. ${ }^{6,8}$ Karena itu sebaiknya dalam upaya meningkatkan kinerja karyawan, pimpinan sebaiknya juga mempertimbangkan faktor-faktor lain yang dapat mempengaruhi kinerja karyawan.

\section{KESIMPULAN}

Berdasarkan hasil analisis deskriptif pada variabel motivasi kerja, tanggapan karyawan secara keseluruhan dalam kategori positif. Berdasarkan hasil analisis deskriptif pada variabel kinerja, tanggapan karyawan secara keseluruhan berada dalam kategori positif. Berdasarkan hasil penelitian yang dilakukan oleh peneliti, motivasi kerja sangat berpengaruh secara signifikan terhadap kinerja karyawan pada Puskesmas Bukit Kayu Kapur Kota Dumai.

\section{UCAPAN TERIMA KASIH}

Peneliti mengucapkan terimakasih kepada Puskesmas Bukit Kayu Kapur atas ijin dan partisipasi seluruh responden pada penelitian ini.

\section{DAFTAR PUSTAKA}

1. Simanjuntak DS. Pengaruh Persepsi Penilaian Prestasi Kerja terhadap Kepuasan Keja Karyawan. J Manaj 2017; 3: 6-13.

2. Hasibuan MSP. Manajemen Sumber Daya Manusia. Ed Revisi Jakarta Bumi Aksara. Epub ahead of print 2011. DOI: 10.1017/CBO9781107415324.004.

3. Kementerian Kesehatan Republik Indonesia. Peraturan Menteri Kesehatan Republik Indonesia No. 75 Tahun 2014 tentang Puskesmas. 75, Indonesia, 2014.

4. Benowitz E. Principles of Management. Idaho: Cliffs Notes, 2001.

5. Silalahi U. Pemahaman Praktis AsasAsas Manajemen. Bandung: Mandar Maju, 2002.

6. Dharmawan Y, Wigati PA, Dwijayanti F. KINERJA PETUGAS DALAM PENCATATAN DAN PELAPORAN PWS KIA DI PUSKESMAS DUREN. $J$ Kesehat Masy; 10. Epub ahead of print 2015. DOI: 10.15294/kemas.v10i2.3383.

7. Salma S. PENGARUH KOMITMEN ORGANISASI, MOTIVASI KERJA DAN PENGALAMAN KERJA TERHADAP KINERJA PEGAWAI HONOR LEPAS PADA PUSKESMAS DI KABUPATEN MOROWALI. e $J$ Katalogis 2016; 4: 73-84. 
8. Aziz MA. Pengaruh Motivasi Kerja, Disiplin Kerja Dan Lingkungan Kerja Terhadap Kinerja Melalui Kepuasan Kerja Pada Pegawai Puskesmas
Kecamatan Balapulang Kabupaten Tegal. Multiplier; $\quad 1, \quad$ http://ejournal.upstegal.ac.id/index.php/MLT/arti cle/view/769 (2016). 